\title{
Pulmonary Mucinous Cystic Neoplasm From Rare Causes of Hemoptysis
}

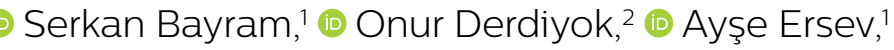 \\ (1) Serdar Evman, ${ }^{1}$ () Volkan Baysungur'
}

\author{
'Department of Thoracic Surgery, \\ University of Heath Science \\ Süreyyapaşa Chest Diseases and \\ Thoracic Surgery Training and \\ Research Hospital, İstanbul, Turkey \\ ${ }^{2}$ Department of Chest Surgery, \\ İstanbul Provincial Health \\ Directorate Prof. Dr. Cemil Taşcıoğlu \\ City Hospital, İstanbul, Turkey \\ Submitted: 01.07.2020 \\ Accepted: 25.03.2021 \\ Correspondence: Onur Derdiyok \\ SBÜ Süreyyapaşa Göğüs Hastalıkları \\ ve Göguüs Cerrahisi Eğitim ve \\ Araştırma Hastanesi, Göğüs \\ Cerrahisi Klinigi, İstanbul, Turkey \\ E-mail: derdiyokonur@gmail.com

Grying \\ Keywords: Hemoptysis; \\ lung; mucinous cystic \\ neoplasm. \\ This work is licensed under a Creative Commons \\ Attribution-NonCommercial 4.0 International License.
}

\begin{abstract}
Cystic mucinous tumors of the lung have been described as histologically different from most lung adenocarcinomas and have a recently identified malignant potential spectrum. Since the literature is very rare, there are often studies such as case reports. In this study, a rare case of primary mucinous cystic tumor of the lung was presented as a contribution to the literature.
\end{abstract}

\section{INTRODUCTION}

Lung primary mucinous cystic tumors are rare neoplasms with histology distinguished from more common pulmonary adenocarcinomas. ${ }^{[1]}$ Although these mucinous neoplasms are histologically similar to ovarian, pancreatic, and appendicular mucinous tumors, there has been considerable confusion regarding the use of various diagnostic terms, including some overlapping terms in the literature. The main reasons for this are very rare. There is very little study in the literature. ${ }^{[2]} \mathrm{A}$ rare case of primary mucinous cystic tumor of the lung, which presented to our clinic with complaints of hemoptysis, was presented as a contribution to the literature.

\section{CASE REPORT}

A 6I-year-old male patient presented to our clinic with the complaint of hemoptysis. On physical examination, blood pressure was $130 / 85 \mathrm{~mm} / \mathrm{Hg}$, pulse was $90 / \mathrm{min}$, fever was $36.5^{\circ} \mathrm{C}$, and respiratory rate was $24 / \mathrm{min}$. There is no specific feature on his physical examination and resume. Laboratory parameters were not found abnormal. A nodule was detected at the computed tomography (CT) of thorax. Positron emission tomography/CT (PET/CT) was performed. In the right upper lobe of the lung, subpleural $12 \mathrm{~mm}$ nodule without FDG involvement was detected (Fig. Ia). Fiberoptic bronchoscopic examination revealed a bleeding area in the right upper lobe. However, endobronchial lesion was not seen and bronchial tree was routinely evaluated. No pathology was found in the bronchial lavage material. There was no evidence of malignancy in aspiration and brush specimens. No acid-fast bacilli were seen. Transthoracic fine-needle aspiration was performed, but the diagnosis could not be obtained. Agglutinin tests for hydatid cysts were negative. The patient was followed for 2 years due to pulmonary nodule and surgical decision was made due to hemoptysis complaints. Pulmonary nod- 

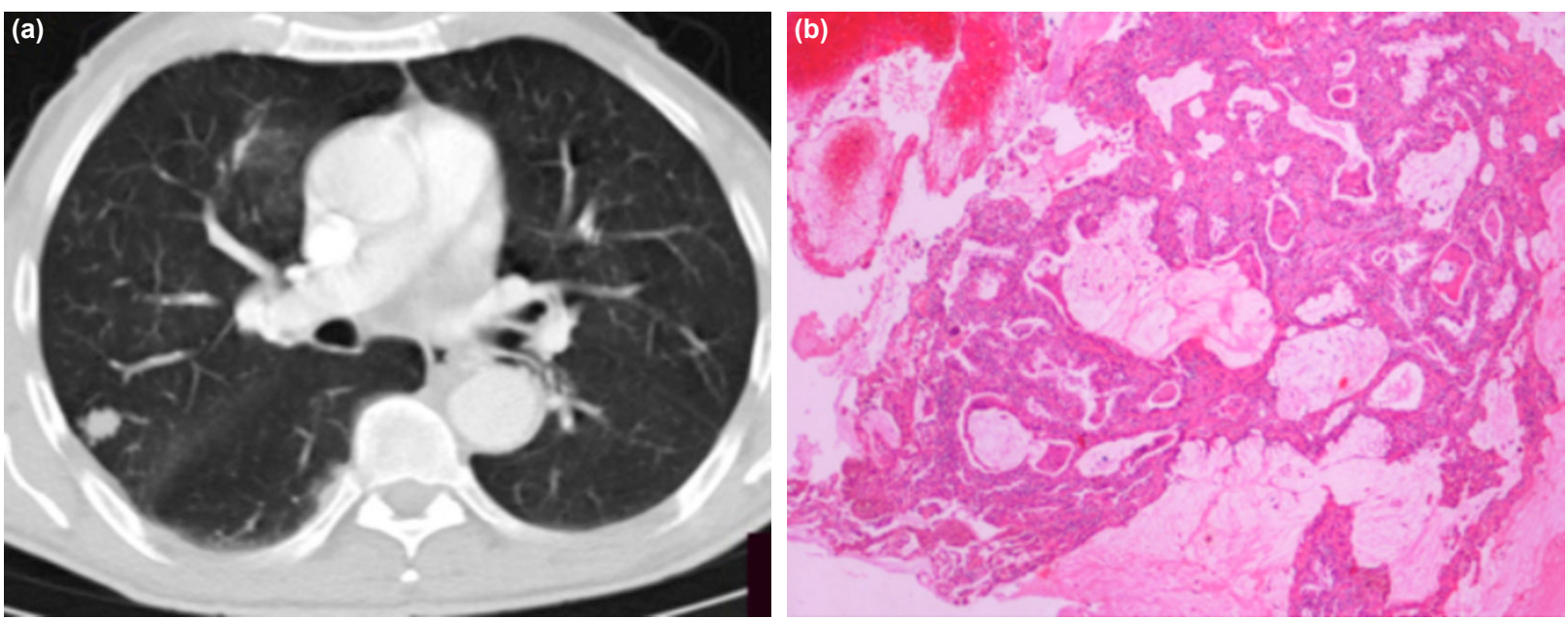

Figure 1. (a) Nodule without FDG uptake in subpleural $12 \mathrm{~mm}$ in the right upper lobe of the lung. (b) (HEX 10) Cystic lesion surrounded by thin fibrous tissue with lumen inline, mucinous high columnar epithelium.

ule was palpated approximately $\mathrm{I} \mathrm{cm}$ in diameter in the right upper lobe of the thoracotomy. After the pathological examination of the frozen material was reported as a benign lesion, the lesion was totally removed by wedge resection. The pathologic lung was reported as a primary mucinous cystic tumor (Fig. Ib). No pathology was detected in the 6-month follow-up of the patient.

\section{DISCUSSION}

Mucinous cyst tumors are a limited tumors. This limitation comes in the form of a partial fibrous capsule. There is a central change in cervical mucin association and neoplastic mucinous epithelium is growing along the alveolar walls. ${ }^{[3]}$ Mucinous (colloid) tumors are defined as a lesion that separates mucin pools containing neoplastic epithelium islands, which are identical to the counterparts in the gastrointestinal tract on the other hand. In such cases, the epithelium may be overdifferentiated and tumor cells sometimes float in the mucin pools..$^{[4]}$ Mucinous cystadenoma is defined as "surrounded by a fibrous wall covered with mucinous localized cystic mass and well-differentiated columnar mucinous epithelium." Differential diagnosis of pulmonary mucinous cystic tumor includes mucous gland adenoma, mucoepidermoid carcinoma, mucinous bronchioloalveolar carcinoma, and metastatic mucinous carcinoma. ${ }^{[5]}$ Mucous gland adenomyoma and mucoepidermoid carcinoma are both endobronchial lesions in place of the peripheral location of the primary mucinous cystic tumors of the lung. Mucous gland adenoma consists of mucoepidermoid carcinoma squamous and mucin-producing cells mixed with intermediate cells, while mucinous enlarged mucinous glands protruding into the bronchial lumen. ${ }^{[6]}$ Radiologically, the symptom is more like a solitary pulmonary nodule. Clinically, it is mostly asymptomatic. In rare cases, symptoms of shortness of breath, chest pain, and stubborn cough have been reported. ${ }^{[3,6]}$ Our surgeon was decided because of our complaints of hemoptysis. Mucinous cyst tumors with hemoptysis complaints are rarely studied in the literature. Studies have shown that optimal treatment of pulmonary mucinous cystic tumors is lobectomy or complete surgical resection. The role of adjuvant treatment is uncertain. However, limited literature on chemotherapy is available. In our case, the tumor was resected with thoracotomy.

\section{CONCLUSION}

Primer mucinous cystic tumors should be kept in mind among the causes of hemoptysis.

\section{Informed Consent}

Written informed consent was obtained from the patient for the publication of the case report and the accompanying images.

\section{Peer-review}

Internally peer-reviewed.

Authorship Contributions

Concept: S.B., O.D.; Design: O.D., A.E.; Supervision: S.E., V.B.; Fundings: O.D., A.E.; Materials: V.B., S.E.; Data: S.B.; Analysis: A.E.; Literature search: V.B.; Writing: S.B.; Critical revision: O.D.

Conflict of Interest

None declared.

\section{REFERENCES}

1. Gao Z, Urbanski SJ. The spectrum of pulmonary mucinous cystic neoplasia: A clinicopathologic and immunohistochemical study of ten cases and review of the literature. Am J Clin Pathol 2005;124:6270.

2. Matsuo T, Yusuke Kimura N, Takamori S, Shirouzu K. A case of recurrent pulmonary mucinous cystadenoma. Eur J Cardiothorac Surg 2005;28:176-7.

3. Schönleben F, Allendorf JD, Qiu W, Li X, Ho DJ, Ciau NT, et al. Mutational analyses of multiple oncogenic pathways in intraductal papillary mucinous neoplasms of the pancreas. Pancreas 2008;36:168-72.

4. Brown J, Frumovitz M. Mucinous tumors of the ovary: Cur- 
rent thoughts on diagnosis and management. Curr Oncol Rep 2014;16:389.

5. Couraud S, Isaac S, Guibert B, Souquet PJ. Bronchial mucous gland adenoma revealed following acute pneumonia. Interact Cardiovasc
Thorac Surg 2012;14:347-9.

6. Igai H, Okumura N, Ohata K, Matsuoka T, Kameyama K, Nakagawa $T$, et al. Pediculate mucinous cystadenoma difficult to differentiate from pleural tumor. Ann Thorac Surg 2008;85:1807-9.

\section{Hemoptizinin Nadir Nedenlerinden Kaynaklanan Pulmoner Müsinöz Kistik Neoplazm}

Akciğerin kistik müsinöz tümörleri histolojik olarak çoğu akciğer adenokarsinomundan farklı olarak tanımlanmıştır ve yakın zamanda tanımlanmış bir malign potansiyel spektrumuna sahiptir. Literatür çok nadir olduğu için genellikle olgu sunumu gibi çalışmalar vardır. Bu çalışmada, nadir görülen bir primer müsinöz kistik tümör olgusu literatüre bir katkı olarak sunulmuştur.

Anahtar Sözcükler: Akciğer; hemoptizi; müsinöz kistik neoplazm. 